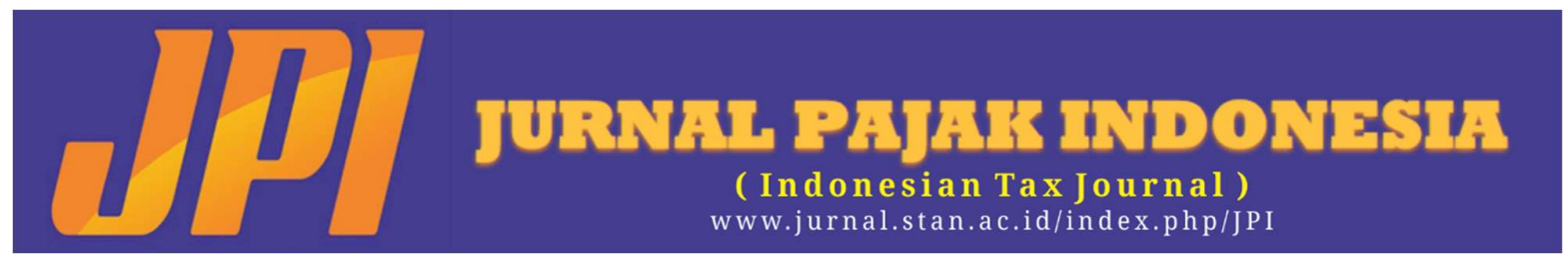

\title{
KEPATUHAN BENDAHARA DESA DALAM MEMENUHI KEWAJIBAN PERPAJAKAN DALAM PERSPEKTIF TEORI PLANNED BEHAVIOR
}

\author{
Nina Andriana \\ Politeknik Keuangan Negara STAN \\ Alamat Korespondensi: nina.andriana@pknstan.ac.id
}

INFORMASI ARTIKEL

Diterima Pertama

[17 02 2020]

Dinyatakan Diterima

[20 02 2020]

KATA KUNCI:

Bendahara Desa, Kewajiban Perpajakan, dan Kepatuhan (Village Treasurer, Tax Obligations, and Compliance).

KLASIFIKASI JEL:

$\mathrm{H} 790$

\begin{abstract}
This study aims to explore the problems faced by the Village Treasurer in fulfilling their tax obligations. This research is a descriptive exploratory qualitative research by analyzing various literatures, regulations, theories, and related researchs. The results showed that most villages have not fully implemented their tax obligations. The disobedience of the Village Treasurer in fulfilling his obligations is seen from the perspective of Planned Behavior Theory caused by several factors, namely: (1) the attitude of the treasurer's behavior that does not fully understand the importance of taxes for the nation and state, (2) subjective norms namely Village Treasurer do not feel that the implementation of taxation obligations is the desired action by the closest important people such as Central and Regional Governments, Village Heads as superiors, colleagues, and (3) Perception of behavioral control felt by Village Treasurers that implementation of tax obligations is sufficient complicated so that the Village Treasurer has not done it optimally.

To increase the compliance of the Village Treasurer in meeting their obligations, it is necessary to provide understanding through training, outreach, and workshops, intensive guidance and supervision from the Village Head, and the role of the regional government as village supervisors through coaching by the Inspectorate.
\end{abstract}

ABSTRAK

Penelitian Penelitian ini bertujuan untuk menggali permasalahan yang dihadapi oleh Bendahara Desa dalam pemenuhan kewajiban perpajakannya. Penelitian ini merupakan penelitian kualitatif deskriptif eksploratif dengan melakukan analisis atas berbagai literatur, peraturan, teori, dan penelitian yang terkait. Hasil penelitian menunjukkan bahwa sebagian besar desa belum sepenuhnya melaksanakan kewajiban perpajakannya. Ketidakpatuhan Bendahara Desa dalam memenuhi kewajibannya dilihat dari perspektif Planned Behavior Theory disebabkan oleh beberapa faktor yaitu: (1) sikap perilaku bendahara yang belum sepenuhnya memahami pentingnya pajak bagi bangsa dan negara, (2) norma subjektif yaitu Bendarahara Desa belum merasakan bahwa pelaksanaan kewajiban perpajakan merupakan tindakan yang diinginkan oleh orang-orang penting terdekat seperti: Pemerintah Pusat dan Daerah, Kepala Desa sebagai atasan, rekan, dan (3) Persepsi kontrol perilaku yang dirasakan oleh Bendahara Desa bahwa pelaksanaan kewajiban perpajakan merupakan hal yang cukup rumit sehingga Bendahara Desa belum melakukannya secara optimal. Untuk meningkatkan kepatuhan Bendahara Desa dalam memenuhi kewajibannya diperlukan pemberian pemahaman melalui pelatihan, sosialisasi, maupun workshop, pembinaan dan pengawasan secara intensif dari Kepala Desa, dan peran pemerintah daerah sebagai pembina desa melalui pembinaan oleh Inspektorat. 


\section{PENDAHULUAN}

\subsection{Latar Belakang}

Seperti yang kita ketahui bersama bahwa beberapa tahun terakhir penerimaan perpajakan pemerintah pusat mengalami shortfall, yang berarti bahwa penerimaan perpajakan masih di bawah target yang telah ditetapkan. Padahal kalau kita lihat penerimaan perpajakan merupakan komponen utama dalam APBN yang secara prosentase komposisi penerimaan perpajakan lebih dari $80 \%$. Dengan adanya shortfall pajak yang cukup besar berarti menimbulkan potensi tidak terdanainya belanja pemerintah. Data terkait dengan shortfall perpajakan dari tahun 2014 sampai tahun 2018 adalah sebagai berikut:

Tabel 1.1 Data Penerimaan Pajak tahun 2014 s.d. 2018 (dalam Trilyun rupiah)

\begin{tabular}{|c|c|c|c|c|}
\hline Tahun & $\begin{array}{c}\text { Target } \\
\text { Penerimaan } \\
\text { Pajak }\end{array}$ & $\begin{array}{c}\text { Realisasi } \\
\text { Penerimaan } \\
\text { pajak }\end{array}$ & $\begin{array}{c}\text { Selisih } \\
\text { (shortfall) }\end{array}$ & $\begin{array}{c}\text { Prosentase } \\
\text { Penerimaan }\end{array}$ \\
\hline 2014 & 985 & 1.072 & 87 & $91,9 \%$ \\
\hline 2015 & 1.294 & 1.055 & 239 & $81,5 \%$ \\
\hline 2016 & 1.539 & 1.283 & 256 & $83,4 \%$ \\
\hline 2017 & 1.283 & 1.147 & 136 & $89,4 \%$ \\
\hline 2018 & 1.424 & 1.316 & 108 & $92 \%$ \\
\hline
\end{tabular}

Sumber: www.cnbcindonesia.com

Adapun untuk tahun 2019 menurut bisnis.com jumlah shortfall pajak adalah sebesar Rp245,5 triliun atau realisasi hanya sebesar Rp1.332,1 trilliun dari target penerimaan dalam APBN sebesar Rp1.577,56 triliun. Prosentase realisasi penerimaan pajak tahun 2019 hanya sebesar $84,4 \%$. Guna mengurangi shortfall penerimaan pajak dan untuk meningkatkan pendapatan perpajakan perlu digali lebih jauh mengenai potensi perpajakan yang masih mungkin untuk ditingkatkan. Salah satu alternatif yang dapat dipertimbangkan adalah penerimaan perpajakan yang berasal dari Pajak Bendahara Desa.

Desa sebagai entitas yang mandiri saat ini mempunyai keuangan yang cukup besar yang secara otomatis akan menjadi belanja bagi desa. Atas belanja desa tersebut timbul potensi perpajakan bagi pemerintah pusat, baik pajak penghasilan maupun pajak lainnya. Sejak tahun 2015, Desa memperoleh dana desa yang berasal dari pemerintah pusat. Jumlah Dana Desa yang digelontorkan oleh pemerintah pusat dari tahun ke tahun cenderung meningkat. Pada tahun 2015 pemerintah pusat menggelontorkan dana desa sebesar Rp20,67 trilliun. Pada tahun 2016 pemerintah pusat menaikkan jumlah dana desa menjadi sebesar Rp46,98 trilliun. Kenaikan dana desa tersebut cukup fantastis karena dua kali lipat lebih. Pada tahun 2017 pemerintah menaikkan kembali dana desa meskipun tidak sebesar tahun sebelumnya. Jumlah dana desa pada tahun 2017 adalah sebesar Rp60 trilliun, dan kembali naik di tahun 2018 menjadi Rp70 trilliun. Untuk tahun 2019 jumlah dana desa yang digelontorkan relatif sama dengan tahun 2018 yaitu sebesar Rp70 trilliun. Sedangkan pada tahun 2020 pemerintah menganggarkan dana desa yang akan ditransfer ke desa sebesar Rp72 trilliun. Jika dirata-rata dengan jumlah desa yang sekitar 74.000 desa maka setiap desa akan memperoleh dana sekitar Rp1 milyar. Jumlah ini bukanlah jumlah yang sedikit.

Selain dana desa, desa juga memperoleh sumber pendapatan lain yang akan digunakan untuk belanja desa. Sumber pendapatan desa antara lain Pendapatan Asli Desa (PADes), Alokasi Dana Desa, Dana Desa, Bagi Hasil Pajak Daerah, dan Lain-lain pendapatan desa yang sah. Semua pendapatan desa akan digunakan untuk membiayai semua kegiatan desa yang otomatis menjadi belanja desa. Atas belanja desa tersebut timbul potensi perpajakan yang akan dipotong atau dipungut oleh Bendahara Desa.

Pajak atas belanja desa akan dipotong dan/atau dipunggut oleh Bendahara Desa. Hal ini sesuai dengan Permendagri nomor 113 tahun 2014 tentang Pengelolaan Keuangan Desa, terutama pasal 31, yang sekarang telah diubah dengan Permendagri 20 tahun 2018, yang menyatakan "Bendahara desa sebagai wajib pungut pajak penghasilan (PPh) dan pajak lainnya, wajib menyetorkan seluruh penerimaan potongan dan pajak yang dipungutnya ke rekening kas negara sesuai dengan ketentuan peraturan perundang-undangan." Mengacu pada hal tersebut maka Bendahara Desa mempunyai kewajiban untuk melakukan pemotongan dan/atau pemungutan pajak atas belanja yang berasal dari APBDes. Kedua, bahwa Bendahara Desa mempunyai kewajiban untuk menyetor setiap pajak yang telah dipotong dan/atau dipungut sesuai dengan ketentuan yang berlaku.

Dengan melihat besarnya dana yang dikelola oleh desa maka ada potensi perpajakan yang cukup besar yang dikelola oleh Bendahara Desa. Semakin Bendahara Desa tertib, taat, dan patuh dalam melakukan kewajiban perpajakannya maka semakin besar penerimaan pajak yang dapat diperoleh oleh pemerintah. Sehingga ini merupakan potensi perpajakan untuk mengurangi shortfall perpajakan yang selama ini kita alami.

Bendahara Desa mempunyai kewajiban perpajakan yang potensial, namun saat ini belum semua Bendahara Desa melakukan kewajiban perpajakannya secara patuh. Salah satunya adalah yang terjadi di Kabupaten Banjar. Hasil evaluasi pajak Dana Desa, diketahui sebagian besar desa belum sepenuhnya melaksanakan kewajiban pajak. Terdapat tiga empat desa di masing-masing Kecamatan Kabupaten Banjar yang nihil atau sama sekali tidak ada pajaknya sejak menerima Dana Desa sejak Tahun 2015. Sebagian desa belum optimal pajaknya dengan berpatokan pada besar pajak dibanding pagu atau jenis kegiatan-kegiatan sebagai pelaksanaan APBDesa atau tax collection (pajak.go.id). Sakina (2017) menyatakan bahwa kepatuhan Bendahara Desa di Sleman belum memenuhi syarat kepatuhan formil maupun materil dalam melaksanakan kewajiban perpajakannya.

Berdasarkan data dan hasil diskusi penulis dengan salah satu pejabat di KPP Ciawi, diperoleh informasi bahwa Bendahara Desa di lingkungan KPP Ciawi sampai saat ini belum sepenuhnya melakukan kewajiban perpajakannya, terutama dalam hal 
pelaporan pajak. Yon Arsal, Direktur Potensi, Kepatuhan dan Penerimaan Ditjen Pajak, (saat ini staf ahli penerimaan) menyatakan bahwa meskipun transfer Pemerintah Pusat untuk daerah dan Dana Desa terus meningkat secara signifikan, namun penerimaan pajak dari aktivitas di daerah masih rendah, berada di kisaran 3,6\% (Katadata 2017).

Meskipun telah ada beberapa penelitian terkait dengan tingkat kepatuhan Bendahara Desa dalam melakukan kewajiban perpajakannya, namun sampai saat ini tingkat kepatuhan Bendahara Desa dalam melaksanakan kewajibannya masih rendah. Kondisi tersebut menjadi menarik untuk dikaji lebih jauh kenapa Bendahara Desa belum patuh dalam melaksanakan kewajiban perpajakannya. Peneliti berusaha untuk mencari tahu lebih jauh apa yang menjadi penyebab atau kendala Bagi Bendahara Desa dalam melaksanakan kewajiban perpajakannya.

\subsection{Tujuan Penelitian}

Penelitian ini bertujuan untuk memetakan penyebab belum patuhnya Bendahara Desa dalam melakukan kewajiban perpajakannya, meliputi kewajiban untuk membuat/memiliki Nomor Pokok Wajib Pajak, kewajiban untuk memotong dan/atau memungut pajak atas belanja Desa yang meliputi Pajak Penghasilan Pasal 21, Pajak Penghasilan Pasal 22, Pajak Penghasilan Pasal 23, Pajak Penghasilan Pasal 4 ayat 1 , maupun PPN dan PPnBM. Selain itu peneliti ingin memberi masukan kepada pemerintah dalam meningkatkan penerimaan pajak melalui peningkatan kepatuhan Bendahara Desa dalam memenuhi kewajiban perpajakannya, terutama pemotongan, pemungutan, dan penyetoran pajak ke kas negara, terutama ditinjau dari teori Planned Behavior.

\section{KERANGKA TEORITIS}

\subsection{Bendahara Desa}

Bendahara Desa menurut permendagri 113 Tahun 2014 adalah unsur staf sekretariat desa yang membidangi urusan administrasi keuangan untuk menatausahakan keuangan desa, sementara menurut Permendagri 20 Tahun 2018 tentang Pengelolaan Keuangan Desa yang merupakan pengganti dari Permendagri 113 Tahun 2015, menyatakan tugas Bendahara Desa dilakukan oleh Kaur Keuangan. Pasal 8 ayat (1) menyatakan Kaur Keuangan sebagaimana dimaksud dalam Pasal 4 huruf c melaksanakan fungsi kebendaharaan. Sedangkan dalam ayat (2) disebutkan tugas Kaur Keuangan yaitu:

a. menyusun RAK Desa; dan

b. melakukan penatausahaan yang meliputi menerima, menyimpan, menyetorkan/ membayar, menatausahakan, dan mempertanggungjawabkan penerimaan pendapatan desa dan pengeluaran dalam rangka pelaksanaan APBDesa.

Dalam ayat 3 lebih lanjut dinyatakan bahwa Kaur Keuangan dalam melaksanakan fungsi kebendaharaan memiliki Nomor Pokok Wajib Pajak pemerintah Desa.
Dengan mengacu kepada Permendagri 20 Tahun 2018 maka Bendahara Desa sudah tidak lagi ditunjuk staf khusus yang bertugas sebagai Bendahara. Tugas Bendahara Desa akan dipegang dan dilaksanakan oleh Kaur Keuangan. Kaur Keuangan inilah yang melaksanakan fungsi kebendaharaan dan melaksanakan tugas Bendahara yaitu meliputi menerima, menyimpan, menyetorkan/membayar, menatausahakan, dan mempertanggungjawabkan penerimaan pendapatan Desa dan pengeluaran dalam rangka pelaksanaan APB Desa, sehingga tidak ada lagi staf yang ditugaskan sebagai Bendahara Desa.

\subsection{Kewajiban dan Jenis Perpajakan Bendahara Desa}

Belanja desa yang merupakan pengeluaran desa atas beban APBDes dikenakan pajak sesuai dengan ketentuan yang berlaku. Dalam pasal 58 Permendagri 20 Tahun 2018 dinyatakan bahwa setiap pengeluaran kas Desa yang menyebabkan beban atas anggaran Belanja Desa dikenakan pajak sesuai dengan ketentuan peraturan perundangan mengenai perpajakan yang berlaku. Pemotongan pajak dilakukan oleh Kaur Keuangan sebagai Bendahara Desa. Adapun kewajiban Kaur Keuangan terkait dengan perpajakan adalah:

a. Mendaftarkan diri untuk memperoleh Nomor Pokok Wajib Pajak;

b. Memotong/memungut pajak atas belanja desa; dan

c. Menyetor pungutan/potongan yang telah dilakukan sesuai dengan ketentuan yang berlaku.

Pemotongan pajak dilakukan oleh Bendahara terhadap pengeluaran kas desa atas beban belanja pegawai, belanja barang dan jasa, dan belanja modal. Aribowo dan Usman (2018) menyatakan pemotongan pajak dan/atau pemungutan pajak akan dilakukan oleh bendahara atas transaksi-transaksi yang merupakan objek pemotongan dan pemungutan. Dengan demikian bahwa untuk pemotongan dan pemungutan pajak maka harus mengacu kepada ketentuan perpajakan.

Meskipun menurut Permendagri 20 Tahun 2018 kewajiban Bendahara yang diatur hanya memotong/memungut dan menyetor, namun kalau kita mengacu pada ketentuan umum perpajakan maka Bendahara seyogyanya juga punya kewajiban melaporkan, apalagi di pasal 8 ayat 3 disebut bahwa Kaur Keuangan dalam menjalankan tugas kebendaharaannya memiliki Nomor Pokok Wajib Pajak (NPWP). Dengan adannya NPWP maka Kaur Keuangan sebagai Bendahara wajib melaporkan kewajiban perpajakannya.

Aribowo dan Usman (2018) menyatakan bahwa kewajiban bendahara desa sebagai pemotong dan/atau pemungut pajak adalah meliputi: (a) mendaftarkan diri sebagai Wajib Pajak, (b) melakukan pemotongan dan/atau pemungutan atas transaksi yang terjadi, (c) menyetorkan pajak yang telah dipotong dan/atau dipungut ke kas negara, (d) melaporkan pemotongan dan/atau pemungutan pajak 
ke KPP tempat bendahara terdaftar, dan (e) memberikan bukti potong/pungut kepada pihak yang dipotong atau dipungut.

Adapun jenis pajak yang harus dipotong/dipungut oleh Bendahara baik dalam Permendagri nomor 113 tahun 2014 maupun dalam Permendagri nomor 20 tahun 2018 tidak dinyatakan secara secara jelas. Dalam Permendagri 113 tahun 2014 hanya disebut Pajak Penghasilan dan Pajak lainnya sesuai dengan ketentuan yang berlaku. Dalam ketentuan lebih lanjut dinyatakan bahwa potongan/pungutan pajak itu dilakukan atas belanja desa yang berupa belanja pegawai, belanja barang dan jasa, serta belanja modal sehingga secara umum pajak yang dipotong/dipungut mengikuti pajak bendahara pada umumnya.

Direktorat Jenderal Pajak (2006) menyatakan bahwa kewajiban Bendahara Pemerintah adalah selain harus mendaftarkan diri sebagai Wajib Pajak, Bendahara wajib memungut dan memotong pajak yang meliputi:

a. Pajak Penghasilan (PPh) pasal 21 dan pasal 26, yaitu pajak yang dipotong atas penghasilan sehubungan dengan pekerjaan, jasa, atau kegiatan dengan nama dan dalam bentuk apa pun yang diterima atau diperoleh Wajib Pajak orang pribadi dalam negeri. Pemotongan pajak ini dilakukan ketika dibayar gaji, upah, honorarium, atau sejenisnya yang dibayarkan kepada orang pribadi;

b. PPh Pasal 22, yaitu pajak yang dipungut sehubungan dengan pembayaran atas penyerahan barang. Atas pajak PPh pasal 22 ini ada pengecualian yaitu: Pembayaran yang jumlahnya paling banyak Rp2.000.000 dan tidak terpecahpecah serta transaksi untuk pembelian BBM, BB, pelumas, dan benda-benda pos, serta pemakaian air maupun listrik;

c. PPh Pasal 23, yaitu pajak yang dipotong sehubungan dengan adanya penghasilan dengan nama dan dalam bentuk apa pun yang dibayarkan, disediakan untuk dibayarkan, atau telah jatuh tempo pembayarannya oleh badan pemerintah, subjek pajak badan dalam negeri, penyelenggara kegiatan, bentuk usaha tetap, atau perwakilan perusahaan luar negeri lainnya kepada Wajib Pajak dalam negeri atau bentuk usaha tetap;

d. PPh Pasal 4 ayat (2), yaitu pajak yang dipotong atas transaksi penghasilan berupa hadiah undian, penghasilan transaksi pengalihan harta berupa tanah dan/atau bangunan, usaha jasa konstruksi, usaha real estate, penghasilan sewa atas tanah dan/atau bangunan, dan penghasilan tertentu lainnya; dan

e. Pajak Pertambahan Nilai (PPN), yaitu pajak atas konsumsi yang dikenakan atas penyerahan Barang Kena Pajak dan/atau Jasa Kena Pajak oleh Pengusaha Kena Pajak Rekanan.

f. Bea Materai

Bendahara Desa pada dasarnya adalah bendahara pemerintah sehingga mempunyai kewajiban yang sama dengan Bendahara Pemerintah pada umumnya. Seyogyanya selain melakukan pemotongan/pemungutan dan penyetoran, maka seharusnya Bendahara Desa juga melakukan pelaporan.

\subsection{Kepatuhan Pajak}

Dalam KBBI Daring patuh berarti suka menurut (perintah dan sebagainya); taat (pada perintah, aturan, dan sebagainya); berdisiplin. Sementara kepatuhan berarti sifat patuh atau ketaatan. Sedangkan Gibson (1991) dalam Agus Budiatmanto (1999), kepatuhan adalah motivasi seseorang, kelompok atau organisasi untuk berbuat atau tidak berbuat sesuai dengan aturan yang telah ditetapkan. Perilaku patuh seseorang merupakan interaksi antara perilaku individu, kelompok dan organisasi. Dengan demikian kepatuhan pajak dapat diartikan sebagai sifat patuh atau ketaatan terhadap ketentuan perpajakan. Subandi dan Fadhil (2018) menyatakan kepatuhan pajak dapat diartikan sebagai kesadaran Wajib Pajak dalam melaksanakan kewajiban perpajakannya sesuai peraturan perundang-undangan perpajakan secara baik dan benar.

Jatmiko (2006) menyatakan bahwa kepatuhan Wajib Pajak terkait dengan sikap Wajib Pajak dalam membuat penilaian terhadap pajak itu sendiri. Persepsi seseorang untuk membuat penilaian mengenai orang lain sangat dipengaruhi oleh kondisi internal maupun eksternal orang tersebut. Perilaku yang disebabkan secara internal adalah perilaku yang diyakini berada di bawah kendali pribadi individu itu sendiri, sedangkan perilaku yang disebabkan secara eksternal adalah perilaku yang dipengaruhi dari luar, artinya individu akan terpaksa berperilaku karena situasi.

Dengan mengacu pada definisi di atas dapat ditarik kesimpulan bahwa kepatuhan Wajib Pajak sangat erat hubungannya dengan sikap seseorang, dalam hal ini sikap bendahara Desa dalam menjalankan kewajiban perpajakannya. Kepatuhan berarti sikap patuh dan tunduk yang ditunjukkan oleh Bendahara Desa dalam memenuhi kewajiban perpajakannya. Selain tunduk, maka dalam kepatuhan juga mencerminkan sikap ketaatan terhadap suatu aturan. Kepatuhan juga berarti kedisiplinan Bendahara Desa dalam melakukan kewajiban perpajakan meliputi pemotongan/ pemungutan dan penyetoran pajak.

Kepatuhan Bendahara desa sebagai Wajib Pajak erat hubungannya dengan sikap Wajib Pajak dalam melakukan penilaian atas kewajiban perpajakan yang akan dilakukannya. Penilaian Wajib Pajak akan menciptakan persepsi dalam diri Wajib Pajak. Persepsi ini kemudian akan mendorong Wajib Pajak untuk bertindak apakah dia akan melaksanakan kewajiban perpajakannya atau tidak.

\subsection{Teori Perilaku Terencana (Planned Behavior)}

Teori Perilaku Terencana menjelaskan mengenai perilaku yang dilakukan oleh seorang individu. Teori Planned Behavior pada dasarnya merupakan pengembangan dari teori Reasoned Action. Reasoned Action Theory menjelaskan bahwa perilaku individu 
didorong oleh dua hal yaitu sikap perilaku dan norma subjektif. Sedangkan dalam Planned Behavior Theory ditambahkan sebuah variabel yang disebut sebagai kontrol perilaku persepsian (perceived behavioral control). Penambahan variabel ini dimaksudkan untuk mengontrol perilaku individual yang dibatasi oleh kekurangan-kekurangannya dan keterbatasanketerbatasan dari kekurangan sumber-sumber daya yang digunakan untuk melakukan perilakunya.

Ada tiga hal yang dijelaskan dalam Planned Behavior Theory yang mendorong perilaku seorang individu yaitu: sikap perilaku, norma subjektif, dan persepsi kontrol perilaku. Sikap perilaku menjadi dasar bagi seseorang untuk melakukan sesuatu tindakan dengan pertimbangan menguntungkan/bermanfaat atau tidak menguntungkan/tidak bermanfaat. Faktor kedua adalah norma subjektif, yaitu kondisi dan tekanan sosial yang dirasakan oleh seseorang untuk melakukan atau tidak melakukan suatu tindakan. Dan yang ketiga adalah persepsi kontrol perilaku hal ini mendasarkan pada kondisi bahwa seseorang akan melakukan sesuatu dengan pertimbangan kemudahan atau kesulitan dalam melakukan sesuatu. Jika suatu hal dianggap mudah untuk dilakukan maka seseorang akan melakukannya namun jika hal tersebut dianggap sulit maka ia akan enggan untuk melakukannya. Tindakan yang muncul sangat tergantung pada persepsi atas pengalaman dalam melakukan suatu tindakan.

Sikap merupakan komponen pendorong atas perilaku seseorang. Seseorang berkeinginan untuk melakukan atau tidak melakukan sesuatu tindakan sangat didasari pada sikap yang dimiliki oleh individu tersebut. Sikap terhadap perilaku merupakan kecenderungan untuk menanggapi hal-hal yang disenangi ataupun yang tidak disenangi pada suatu objek, orang, institusi atau peristiwa (Ajzen, 1991). Ketika seseorang mempunyai sikap positif terhadap sesuatu hal maka yang bersangkutan akan senang untuk melakukannya dan sebaliknya apabila seseorang mempunyai sikap yang negatif akan suatu hal maka ia cenderung untuk tidak melakukannya. Mengacu pada kondisi tersebut Bendahara Desa akan melaksanakan kewajiban perpajakan jika mereka memandang bahwa apa yang dilakukan memberikan manfaat yang positif sehingga mereka dengan sukarela mau untuk melakukan kewajibannya.

Norma subjektif, mengadung pengertian bahwa tindakan seseorang sangat dipengaruhi oleh normanorma yang dimilikinya. Setyorini dan Mudiantono (2013) menyatakan norma subjektif diasumsikan sebagai suatu fungsi dari beliefs yang secara spesifik seseorang setuju atau tidak setuju untuk menampilkan suatu perilaku. Kepercayaankepercayaan yang termasuk dalam norma-norma subjektif disebut juga kepercayaan normatif (normative beliefs). Seorang individu akan berniat menampilkan suatu perilaku tertentu jika ia mempersepsi bahwa orang-orang lain yang penting berfikir bahwa ia seharusnya melakukan hal itu. Orang lain yang penting tersebut bisa pemerintah, pasangan, atasan, rekan kerja, sahabat, dokter, dsb. Dengan demikian seseorang akan melakukan sesuatu tindakan jika menurutnya bahwa orang-orang penting di sekitarnya menginginkan ia melakukan tindakan tersebut, namun jika orang-orang penting di sekitarnya dirasa tidak menganggap penting bagi dia untuk melakukan hal tersebut maka kecenderungannya ia tidak melakukan hal tersebut.

Kontrol perilaku persepsian merupakan persepsi yang dimiliki oleh seseorang terkait dengan kemudahan dan kerumitan atas suatu pekerjaan. Seseorang akan melakukan suatu tindakan jika ia mempunyai persepsi bahwa tindakan tersebut mudah baginya untuk dilakukan, dan sebaliknya seseorang enggan untuk melakukan sesuatu jika dalam persepsi dia pekerjaan tersebut sulit/rumit untuk dilaksanakan. Dengan demikian kontrol perilaku persepsian pada dasarnya merupakan suatu tingkat kepercayaan seseorang mengenai seberapa sederhana atau kompleksnya melaksanakan suatu tindakan. Kontrol perilaku dapat juga berarti sebagai tingkat pemahaman individu mengenai sederhana atau kompleksnya melakukan tindakan atas dasar pada persepsi yang tercipta dari pengalaman terdahulu dan kendala yang dapat dicari solusinya dalam melakukan suatu perbuatan. Seseorang yang mempunyai sikap dan norma subjektif yang mendukung dalam melakukan perbuatan tertentu akan sangat bergantung pada dukungan kontrol perilaku persepsian yang ia miliki.

\section{METODE PENELITIAN}

\subsection{Jenis Penelitian}

Penelitian ini adalah penelitian kualitatif deskriptif analitis dengan tinjuan literatur dan teori. Penelitian ini mencoba menganalisis kondisi yang ada saat ini berdasarkan literatur dan penelitian-penelitian yang telah dilakukan oleh orang lain. Data sekunder diperoleh dari literatur dan penelitian terdahulu.

\subsection{Metode Analisis Data}

Penelitian ini merupakan penelitian studi literatur. Analisis data dilakukan dalam beberapa tahap. Tahap pertama peneliti melakukan pengumpulan data penelitian terkait dengan kepatuhan Wajib Pajak secara umum. Tahap kedua peneliti mengikhtisarkan faktor-faktor yang mempengaruhi kepatuhan Wajib Pajak. Tahap ketiga peneliti melakukan pengelompokkan faktor dan menyaring faktor tersebut dan mengaitkan dengan teori planned behavior. Tahap keempat menarik kesimpulan. Dan pada tahap akhir peneliti mencoba memberikan saran sesuai dengan kesimpulan yang dibuat pada tahap kelima.

\section{HASIL PENELITIAN}

\subsection{Analisis Penelitian Kepatuhan Pajak}

Penelitian terkait dengan kepatuhan perpajakan merupakan penelitian yang telah lama dilakukan oleh para peneliti. Namun penelitian yang spesifik terkait 
dengan kepatuhan Bendahara Desa masih sangat sedikit. Untuk itu dalam penelitian ini analisis penelitian terdahulu tidak spesifik ke kepatuhan Bendahara Desa tetapi lebih bersifat umum.

Penelitian Harjowiryono (2019) menyatakan bahwa Pengetahuan Perpajakan, Sikap Terhadap Kewajiban Perpajakan, Kualitas Pelayanan Perpajakan, Kemudahan Aplikasi Perpajakan dan Peran DJPb secara bersama-sama memiliki pengaruh terhadap Kepatuhan Pajak Bendahara Pemda. Lebih lanjut dijelaskan bahwa secara parsial Pengetahuan Perpajakan Wajib Pajak mempunyai pengaruh positif signifikan terhadap kepatuhan perpajakan. Selain itu variable Sikap Terhadap Kewajiban Perpajakan juga mempunyai pengaruh yang sama yaitu positif signifikan. Variabel Kualitas Pelayanan Perpajakan dan Kemudahan Aplikasi Perpajakan juga memberikan pengaruh positif signifikan terhadap Kepatuhan. Sedangkan variable Peran DJPb tidak berpengaruh secara signifikan terhadap kepatuhan perpajakan Bendahara.

Handi Subandi dan Muhammad Irvanuddin Ibnu Fadhil pada tahun 2018 melakukan penelitian dengan judul "Analisis Faktor-Faktor yang Mempengaruhi Kepatuhan Pajak Bendahara Desa di Kota Batu". Hasil penelitian menunjukkan bahwa variabel pengetahuan pajak, pelayanan pajak, dan sanksi pajak mempunyai pengaruh positif terhadap kepatuhan pajak.

Penelitian Anam, Andini, dan Hartono (2018) menyatakan bahwa kesadaran Wajib Pajak berpengaruh positif terhadap kepatuhan Wajib Pajak. Lebih lanjut dijelaskan bahwa variabel pelayanan fiskus juga berpengaruh positif terhadap kepatuhan Wajib Pajak. Sementara untuk variable sanksi pajak tidak secara langsung berpengaruh terhadap kepatuhan Wajib Pajak.

Nurulita Rahayu pada tahun 2017 melakukan penelitian terkait dengan kepatuhan perpajakan di Kabupaten Bantul dengan judul Pengaruh Pengetahuan Perpajakan, Ketegasan Sanksi Pajak, dan Tax Amnesty terhadap Kepatuhan Wajib Pajak. Hasil penelitian menunjukkan bahwa ketiga variable tersebut mempunyai pengaruh yang positif signifikan.

Wulandari Agustiningsih dan Isroah pada tahun 2016 melakukan penelitian yang terkait dengan Pengaruh Penerapan E-Filing, Tingkat Pemahaman Perpajakan dan Kesadaran Wajib Pajak Terhadap Kepatuhan Wajib Pajak Di KPP Pratama Yogyakarta. Hasil Penelitian menunjukkan bahwa variable penerapan e-filling, pemahaman perpajakan, dan kesadaran Wajib Pajak berpengaruh secara positif terhadap kepatuhan Wajib Pajak.

Nurlis Islamiah Kamil (2015) menyatakan bahwa pengetahuan perpajakan mempengaruhi secara signifikan terhadap kepatuhan Wajib Pajak. Penelitian Nurlis ini dilakukan di wilayah Jabodetabek dan Bandung dengan judul The Effect of Taxpayer Awarness, Knowledge, Tax Penalties and Tax Authorities Services on the Tax Compliance: (Survey on the Individual Taxpayer at Jabodetabek \& Bandung.
Wajib pajak yang memiliki pengetahuan pajak yang tidak memadai dan menganggap bahwa sistem pajak merupakan suatu hal yang kompleks dipandang sebagai faktor terhadap perilaku ketidakpatuhan Wajib Pajak, Saad (2015). Dalam penelitian ini dinyatakan bahwa Wajib Pajak yang tidak memiliki pengetahuan perpajakan yang cukup cenderung tidak patuh terhadap kewajiban perpajakannya.

Susherdianto dan Haryanto (2014) menyatakan bahwa pengetahuan dan pemahaman perpajakan berpengaruh positif dan signifikan terhadap kepatuhan Wajib Pajak orang pribadi yang memiliki usaha di Kota Kudus. Hal ini menegaskan bahwa pengetahuan dan pemahaman perpajakan sangat diperlukan bagi Wajib Pajak guna memenuhi kewajiban perpajakannya.

Penelitian Afni (2013) menyimpulkan bahwa variabel Pengetahuan Perpajakan, Pelayanan Perpajakan dan Sanksi Pajak secara simultan maupun parsial berpengaruh terhadap Kepatuhan Perpajakan.

Aryobimo dan Cahyonowati (2012) menyatakan bahwa kualitas layanan Fiskus mempengaruhi kepatuhan Wajib Pajak dalam menjalankan kewajiban perpajakannya. Ini berarti bahwa semakin bagus layanan yang diberikan oleh fiskus maka Wajib Pajak akan menjadi lebih patuh.

Sandi (2010) menyatakan bahwa kepatuhan pajak dipengaruhi oleh kualitas layanan yang diberikan oleh fiskus dan pengawasan yang dilakukan oleh KPP melalui Accounts Representative. Selain itu Sandi juga meneliti pengaruh konsultansi yang diberikan Accounts representative terhadap kepatuhan Wajib Pajak. Hasil penelitian menunjukkan bahwa konsultansi tidak berpengaruh signifikan.

Penelitian Jatmiko (2006) di Semarang menyatakan bahwa kepatuhan Wajib Pajak dipengaruhi oleh beberapa hal yaitu: (1) sikap WP terhadap pelaksanaan sanksi denda, (2) sikap WP terhadap pelayanan fiskus, dan (3) sikap Wajib Pajak terhadap kesadaran perpajakan. Hasil penelitian menyatakan bahwa ketiga hal tersebut berpengaruh secara positif terhadap kepatuhan perpajakan.

\subsection{Tabulasi hasil penelitian}

Untuk mempermudah pengolahan data penulis melakukan tabulasi hasil penelitian. Tabulasi hasil penelitian dilakukan dengan menyederhanakan faktor-faktor yang mempengaruhi penelitian. Peneliti berusaha melakukan tabulasi penelitian dari tahun ke tahun agar dapat memperoleh gambaran yang lebih komprehensif. Secara umum tabulasi penelitian dapat dibuat sebagai berikut:

Tabel 4.1 Tabulasi Hasil Penelitian

\begin{tabular}{|l|ll|}
\hline \multicolumn{1}{|c|}{ Peneliti } & \multicolumn{2}{|c|}{$\begin{array}{c}\text { Faktor yang mempengaruhi } \\
\text { kepatuhan perpajakan }\end{array}$} \\
\hline Marwanto & 1. & Pengetahuan Perpajakan \\
Harjowiryono & 2. & Sikap terhadap kewajiban \\
$(2019)$ & perpajakan \\
& 3. & Kualitas Pelayanan \\
& 4. & Kemudahan Aplikasi \\
\hline
\end{tabular}




\begin{tabular}{|c|c|}
\hline Peneliti & $\begin{array}{l}\text { Faktor yang mempengaruhi } \\
\text { kepatuhan perpajakan }\end{array}$ \\
\hline & 5. Peran DJPB \\
\hline $\begin{array}{l}\text { Handi Subandi } \\
\text { dan Muhammad } \\
\text { Irvanuddin Ibnu } \\
\text { Fadhil (2018) }\end{array}$ & $\begin{array}{l}\text { 1. Pengetahuan pajak, } \\
\text { 2. Pelayanan pajak, } \\
\text { 3. Sanksi pajak }\end{array}$ \\
\hline $\begin{array}{l}\text { Anam, Andini, dan } \\
\text { Hartono (2018) }\end{array}$ & $\begin{array}{ll}\text { 1. } & \text { Kesadaran Wajib Pajak } \\
\text { 2. } & \text { Pelayanan fiskus juga } \\
\text { 3. } & \text { Sanksi pajak tidak secara } \\
& \text { langsung berpengaruh }\end{array}$ \\
\hline $\begin{array}{l}\text { Nurulita Rahayu } \\
\text { (2017) }\end{array}$ & $\begin{array}{ll}\text { 1. } & \text { Pengetahuan Perpajakan } \\
\text { 2. } & \text { Ketegasan Sanksi Pajak } \\
\text { 3. } & \text { Tax Amnesty } \\
\end{array}$ \\
\hline $\begin{array}{l}\text { Wulandari } \\
\text { Agustiningsih dan } \\
\text { Isroah (2016) }\end{array}$ & $\begin{array}{ll}\text { 1. } & \text { Penerapan E-Filing } \\
\text { 2. } & \text { Tingkat Pemahaman } \\
& \text { Perpajakan } \\
\text { 3. } & \text { Kesadaran Wajib Pajak } \\
\end{array}$ \\
\hline $\begin{array}{l}\text { Nurlis Islamiah } \\
\text { Kamil (2015) }\end{array}$ & Pengetahuan perpajakan \\
\hline Saad (2015) & Pemahaman terhadap perpajakan \\
\hline $\begin{array}{l}\text { Susherdianto dan } \\
\text { Haryanto (2014) }\end{array}$ & $\begin{array}{l}\text { Pengetahuan dan pemahaman } \\
\text { perpajakan }\end{array}$ \\
\hline Afni (2013) & $\begin{array}{ll}\text { 1. } & \text { Pengetahuan Perpajakan } \\
\text { 2. } & \text { Pelayanan Perpajakan } \\
\text { 3. } & \text { Sanksi Pajak }\end{array}$ \\
\hline $\begin{array}{l}\text { Aryobimo dan } \\
\text { Cahyonowati } \\
(2012)\end{array}$ & Kualitas layanan \\
\hline $\begin{array}{l}\text { Nofri Boy Sandi } \\
(2010)\end{array}$ & $\begin{array}{ll}\text { 1. } & \text { Pelayanan } \\
\text { 2. } & \text { Pengawasan } \\
\text { 3. } & \text { Konsultasi } \\
\end{array}$ \\
\hline $\begin{array}{l}\text { Agus Nugroho } \\
\text { Jatmiko (2006) }\end{array}$ & $\begin{array}{ll}\text { 1. } & \text { Sikap WP terhadap } \\
\text { pelaksanaan sanksi } \\
\text { 2. Sikap WP terhadap pelayanan } \\
\text { fiscus } \\
\text { 3. Sikap WP terhadap kesadaran } \\
\text { pajak }\end{array}$ \\
\hline
\end{tabular}

\subsection{Pengelompokkan dan Penyaringan}

Berdasarkan hasil tabulasi tahap pertama peneliti mencoba melakukan tabulasi pada prespektif teori perilaku terencana sebagai berikut:

Tabel 4.2 Tabulasi Perspektif

\begin{tabular}{|l|l|l|l|}
\hline No & Prespektif & \multicolumn{1}{|c|}{ Pengertian } & \multicolumn{1}{|c|}{ Faktor } \\
\hline 1. & $\begin{array}{l}\text { Sikap } \\
\text { Perilaku }\end{array}$ & $\begin{array}{l}\text { Wajib Pajak } \\
\text { mengetahui } \\
\text { manfaat dari } \\
\text { pelaksanaan } \\
\text { kewajiban } \\
\text { pajak }\end{array}$ & $\begin{array}{l}\text { 1. Pengetahuan } \\
\text { perpajakan } \\
\text { 2. Sikap } \\
\text { terhadap } \\
\text { kewajiban } \\
\text { perpajakan } \\
\text { Kesadaran } \\
\text { Wajib Pajak }\end{array}$ \\
\hline 2. & $\begin{array}{l}\text { Norma } \\
\text { Subjektif }\end{array}$ & $\begin{array}{l}\text { Wajib Pajak } \\
\text { menyadari } \\
\text { bahwa } \\
\text { kepatuhan } \\
\text { pajak penting } \\
\text { bagi pihak lain }\end{array}$ & $\begin{array}{l}\text { 1. Sanksi pajak } \\
\text { 2. Pengawasan }\end{array}$ \\
\hline
\end{tabular}

\begin{tabular}{|c|c|c|c|}
\hline 3. & $\begin{array}{l}\text { Persepsi } \\
\text { Kontrol } \\
\text { Perilaku }\end{array}$ & $\begin{array}{l}\text { Wajib Pajak } \\
\text { sukarela } \\
\text { melaksanakan } \\
\text { kewajiban } \\
\text { perpajakannya } \\
\text { jika ia merasa } \\
\text { pelaksanaan } \\
\text { kewajiban } \\
\text { adalah mudah }\end{array}$ & $\begin{aligned} \text { 1. Kemudahan } \\
\text { Aplikasi } \\
\text { 2. Pemahaman } \\
\text { perpajakan } \\
\text { 3. Tax Amnesty } \\
\text { 4. Penerapan E- } \\
\text { Filing } \\
\text { 5. Pelayanan } \\
\text { Perpajakan } \\
\text { 6. Konsultansi }\end{aligned}$ \\
\hline
\end{tabular}

Tabel 4.2 menunjukkan bahwa hasil penelitian terdahulu terkait dengan kepatuhan Wajib Pajak apabila diklasifikasikan dengan pendekatan teori Planned Behavior dapat disederhanakan menjadi tiga faktor utama yang mempengaruhi kepatuhan Wajib Pajak. Ketiga faktor tersebut adalah faktor sikap perilaku, faktor norma subjektif, dan faktor persepsi kontrol perilaku.

\section{KESIMPULAN DAN SARAN}

\subsection{KESIMPULAN}

Bendahara Desa mempunyai kewajiban untuk melakukan pemotongan dan pemungutan pajak atas belanja desa sesuai dengan ketentuan yang berlaku. Hasil pemotongan dan pemungutan wajib disetor ke pemerintah sesuai dengan jenis pajak yang dipotong dan dipungut oleh Bendahara Desa. Meskipun tidak secara jelas dinyatakan Bendahara Desa wajib melaporkan pajak, namun berdasarkan pada Permendagri nomor 20 tahun 2018 Bendahara Desa wajib mempunyai NPWP sehingga Bendahara Desa juga wajib melaporkan pajaknya secara berkala. Selain itu Bendahara Desa pada dasarnya adalah Bendahara Pemerintah sehingga secara umum Bendahara Desa harus mengikuti ketentuan tentang Bendahara Pemerintah dan mereka wajib melaporkan segala pajak yang telah dipotong, dipungut, dan/atau disetor.

Bendahara Desa saat ini belum melaksanakan kewajiban secara optimal. Baik kewajiban pemotongan, pemungutan, dan penyetoran. Ketidakpatuhan Bendahara Desa dalam melakukan kewajiban perpajakan kalau ditinjau dari perspektif teori perilaku terencana disebabkan oleh tiga faktor yaitu:

a. Sikap perilaku. Bendahara Desa bersedia untuk melakukan kewajiban perpajakannya jika hal tersebut menurutnya penting dan sebaliknya. Ketidakpatuhan Bendahara Desa dalam memenuhi kewajiban perpajakan dikarenakan belum sepenuhnya memahami manfaat dari pajak yang dipotong dan dipungut oleh Bendahara Desa. Mereka belum memahami bahwa pajak yang dipungut oleh pemerintah menjadi sumber pemerintah untuk membiayai segala pengeluaran pemerintah yang berdampak pada pertumbuhan ekonomi di wilayah Indonesia.

b. Norma subjektif. Bendahara Desa akan melakukan kewajiban perpajakan secara baik dan benar jika ia memandang bahwa kewajiban perpajakan merupakan hal yang harus dilakukan olehnya karena orang-orang penting di sekitarnya 
menginginkan hal tersebut. Dan sebaliknya Bendahara Desa enggan melakukan kewajiban perpajakannya karena perilaku tersebut bukan perilaku yang sangat penting bagi orang-orang di sekitarnya baik pemerintah, pemerintah daerah, atasan, rekan kerja atau orang-orang lain yang penting bagi kehidupan bendahara. Orang-orang penting di sekitarnya seharusnya memberikan dukungan kepada Bendahara Desa untuk memenuhi kewajiban perpajakannya.

c. Kontrol perilaku persepsian. Persepsi atas kemudahan dalam perpajakan akan mendorong Bendahara Desa untuk memenuhi kewajiban perpajakannya, namun sebaliknya persepsi kerumitan mendorong Bendahara Desa tidak melakukan kewajiban perpajakan secara optimal. Pemberian pemahaman atas tata cara dan prosedur perpajakan bagi Bendahara Desa akan menciptakan perpsepsi bahwa pelaksanaan kewajiban perpajakan bukanlah hal yang rumit.

\subsection{SARAN}

Pada bagian akhir penelitian ini peneliti memberikan saran kepada pihak-pihak berwenang terutama pemerintah, baik pemerintah pusat, daerah, maupun desa agar kita dapat meningkatkan kepatuhan perpajakan pada Bendahara Desa. Adapun saran yang peneliti berikan adalah sebagai berikut:

a. Bendahara desa sebaiknya diberikan pemahaman mengenai pentingnya perpajakan bagi pemerintah Indonesia. Pemberian pemahaman dapat dilakukan melalui pelatihan/workshop/seminar dan/atau kegiatan lainnya yang berfungsi memberikan informasi kepada para Bendahara Desa.

b. Adanya pengawasan dan monitoring dari atasan, Inpsektorat, Kantor Pelayanan Pajak, dan/atau unit terkait. Pengawasan dan monitoring ditekankan pada pentingnya pemenuhan kewajiban perpajakan bagi Bendahara Desa. Bendahara Desa harus merasa bahwa orang-orang di sekitarnya merasa perlu Bendahara Desa melakukan kewajiban perpajakan. Selain itu menurut penulis perlu dibuat ajang penghargaan bagi Bendahara Desa yang telah memenuhi kewajiban perpajakannya dengan baik dan benar, sehingga mereka merasa bahwa pelaporan perpajakan merupakan hal yang sangat penting.

c. Kepatuhan perpajakan juga terkait dengan persepsi kemudahan dalam melakukan kewajiban perpajakannya. Untuk itu, diperlukan pelatihan/workshop terkait dengan kewajiban perpajakan Bendahara Desa serta pendampingan secara berkelanjutan agar mereka merasa bahwa pajak bukanlah hal yang sulit.

\section{DAFTAR PUSTAKA}

\section{Buku Literatur}

Afni, M. (2013). Faktor-Faktor yang Mempengaruhi Kepatuhan Wajib Pajak Bendaharawan
Pemerintah di Kabupaten Rokan Hilir (Doctoral dissertation, Universitas Islam Negeri Sultan Syarif Kasim Riau).

Agustiningsih, W., \& Isroah, I. (2016). Pengaruh Penerapan E-Filing, Tingkat Pemahaman Perpajakan Dan Kesadaran Wajib Pajak Terhadap Kepatuhan Wajib Pajak Di KPP Pratama Yogyakarta. Nominal, Barometer Riset Akuntansi dan Manajemen, 5(2), 107-122.

Ajzen I 1991. The Theory of Planned Behavior. Organizational Behavior and Human Decision Processes. 50: 179 - 211.

Anam, M. C., Andini, R., \& Hartono, H. (2018). Pengaruh Kesadaran Wajib Pajak, Pelayanan Fiskus dan Sanksi Pajak terhadap Kepatuhan Wajib Pajak Orang Pribadi yang Melakukan Kegiatan Usaha dan Pekerjaan Bebas sebagai Variabel Intervening (Studi di KPP Pratama Salatiga). Journal Of Accounting, 4(4).

Aribowo, I., \& Usman, F. (2018). Pendampingan Pelaksanaan Kewajiban Perpajakan Bendahara Desa Gelam Jaya Kecamatan Pasar Kemis Kabupaten Tangerang. Prosiding Sembadha, 1(1), 237-241.

Aryobimo, P. T., \& Cahyonowati, N. (2012). Pengaruh Persepsi Wajib Pajak tentang Kualitas Pelayanan Fiskus terhadap Kepatuhan Wajib Pajak dengan Kondisi Keuangan Wajib Pajak dan Preferensi Risiko sebagai Variabel Moderating (Studi Empiris terhadap Wajib Pajak Orang Pribadi di Kota Semarang) (Doctoral dissertation, Fakultas Ekonomika dan Bisnis).

Budiatmanto, A. (1999). Studi evaluasi kepatuhan Wajib Pajak sebelum dan sesudah reformasi perpajakan tahun 1983 (Doctoral dissertation, [Yogyakarta]: Universitas Gadjah Mada).

Direktorat Jenderal Pajak. (2016). Bendahara Mahir Pajak. Edisi Revisi III.

Harjowiryono, M. (2019). Analisis faktor-faktor yang memengaruhi kepatuhan bendahara pemerintah dalam penyetoran pajak. Indonesian Treasury Review: Jurnal Perbendaharaan, Keuangan Negara dan Kebijakan Publik, 4(3), 195-217.

Jatmiko, A. N. (2006). Pengaruh Sikap Wajib Pajak pada Pelaksanaan Sanksi Denda, Pelayanan Fiskus dan Kesadaran Perpajakan terhadap Kepatuhan Wajib Pajak (Studi Empiris terhadap Wajib Pajak Orang Pribadi di Kota Semarang) (Doctoral dissertation, Program Pasca Sarjana Universitas Diponegoro).

Kamil, N. I. (2015). The Effect of Taxpayer Awareness, Knowledge, Tax Penalties and Tax Authorities 
Services on the Tax Complience:(Survey on the Individual Taxpayer at Jabodetabek \& Bandung). Research Journal of Finance and Accounting, 6(2), 104-111.

Rahayu, N. (2017). Pengaruh pengetahuan perpajakan, ketegasan sanksi pajak, dan Tax amnesty terhadap kepatuhan Wajib Pajak. Akuntansi Dewantara, 1(1), 15-30.

Saad, N. (2014). Tax knowledge, Tax Complexity and Tax Compliance: Taxpayers' view. ProcediaSocial and Behavioral Sciences, 109, 1069-1075.

Sakina, S. M. (2017). Pelaksanaan Kewajiban Perpajakan Oleh Bendahara Desa Dalam Pengelolaan Dana Desa Ditinjau Dari Asas Kepatuhan Di Kecamatan Berbah, Sleman (Doctoral dissertation, Universitas Gadjah Mada).

Sandi, N. B. (2010). Analisis Pengaruh Pelayanan Konsultasi, dan Pengawasan Account Representative Terhadap Kepatuhan Wajib Pajak: Studi Empiris pada Kantor Pelayanan Pajak Tangerang dan Serpong.

Setyorini, N., \& MUDIANTONO, M. (2013). Analisis theory of planned behavior dalam pemilihan produk makanan berlabel halal di kota semarang (Doctoral dissertation, Fakultas Ekonomika dan Bisnis).

Subandi, H., \& Fadhil, M. I. I. (2018). Analisis FaktorFaktor Yang Mempengaruhi Kepatuhan Pajak Bendahara Desa Di Kota Batu. Berkala Akuntansi dan Keuangan Indonesia, 3(1), 1-16.

Susherdianto, R., \& Haryanto, H. (2014). Analisis faktor-Faktor yang Mempengaruhi Tingkat Kepatuhan Wajib Pajak (Studi WPOP Yang Memiliki Usaha Di Kota Kudus) (Doctoral dissertation, Fakultas Ekonomika dan Bisnis).

\section{Peraturan, Situs dan Internet}

Republik Indonesia. Peraturan Menteri Dalam Negeri Nomor 20 Tahun 2018 tentang Pengelolaan Keuangan Desa.

https://katadata.co.id/berita/2017/09/12/setoranpajak-bendahara-pemerintah-seretpengawasan-bakal-diperketat

https://www.cnbcindonesia.com/news/20191226094 259-4-125631/waduh-shortfall-pajak-2019terbesar-sepanjang-sejarah/2

https://pajak.go.id/artikel/mengawal-pajak-danadesa 